\title{
Rhodnius prolixus Malpighian tubules and control of diuresis by neurohormones
}

\author{
SABRINA V. MARTINI, SUZETE B. NASCIMENTO and MARCELO M. MORALES \\ Instituto de Biofísica Carlos Chagas Filho, CCS, Universidade Federal do Rio de Janeiro \\ Cidade Universitária, Ilha do Fundão, 21949-900 Rio de Janeiro, RJ, Brasil \\ Manuscript received on April 5, 2006; accepted for publication on April 25, 2006; \\ presented by LUCIA MENDONÇA PREVIATO
}

\begin{abstract}
Rhodnius prolixus Malpighian tubules (MTs) are a good model for fluid and ion secretion studies in view of the dramatic postprandial diuresis, which follows its massive blood meals. Ingestion of a blood meal equals to 10-12 times their initial body mass, leads to rapid activation of high output by excretory system, which eliminates $40-50 \%$ of the fluid mass. Secretion of ions and water is stimulated 1000 -fold by serotonin and diuretic hormone. These hormones cooperate synergistically to activate adenylate cyclase activity from MTs cells, which increase the level of intracellular cAMP. The anti-diuretic hormones have also an important role in the fluid maintenance of Rhodnius prolixus. Several hours after insect feeding occurs a reduction in urine flow, that has been thought to result from a decreased diuretic hormone release or from a novel mechanism of anti-diuresis involving insect cardioacceleratory peptide $2 \mathrm{~b}$ (CAP2b) and cyclic GMP. In this article it is discussed how the hormone regulation of fluid transport is done in Rhodnius prolixus MTs.
\end{abstract}

Key words: Malpighian tubules, Rhodnius prolixus, hormones, fluid secretion.

\section{INTRODUCTION}

Rhodnius prolixus is a blood-sucking insect well known by for its importance as vector of Chagas disease, especially in Latin America (Lent and Wygodzinsky 1979). The protozoa Tripanosoma cruzi, cause of Chagas disease, is transmitted through the insects belonging the Triatominae subfamily, where the Rhodnius prolixus and Triatoma infestans are common vectors. The protozoa are found in the intestinal tract of both vectors (Dias et al. 1997). Rhodnius prolixus removes from its mammalian host a volume of blood enough to increase its own weight by about tenfold in larval stage and two or three times in the adult insect stage. In this engorged state, the insect is vulnerable to predation and must eliminate the excess of water and salt to reduce its own volume (Maddrell 1976).

Correspondence to: Marcelo M. Morales

E-mail: mmorales@biof.ufrj.br
A mixture of about $55 \%$ (by volume) of plasma and $45 \%$ of cells usually composes the ingested mammalian blood. The mammalian cells have a normal $\mathrm{K}^{+}$rich cytoplasm $(150 \mathrm{mEq} / \mathrm{l})$, while the plasma has a high concentration of sodium chloride $\left(\mathrm{Na}^{+}: 140 \mathrm{mEq} / \mathrm{l}\right.$ and $\mathrm{Cl}^{-}$: $100 \mathrm{mEq} / \mathrm{l}$ ) (Maddrell and Phillips 1975). When Rhodnius prolixus takes blood from mammalian host, it ingests a fluid containing blood cells suspended in sodium-rich plasma, which is distinctly hyposmotic (280-300 mOsm $/ \mathrm{kgH}_{2} \mathrm{O}$ ) to its own hemolymph (370 $\mathrm{mOsm} / \mathrm{kgH}_{2} \mathrm{O}$ ). To reduce the bulk and concentrate the nutritious part of the meal and, in addition, prevent dilution of its hemolymph, the insect rapidly excretes a markedly hyposmotic fluid of high-sodium content (Maddrell 1976).

The first essential element in Rhodnius prolixus excretion process is the rapid transport, across the gut epithelia, of sodium chloride-based solution, which is isosmotic, compared to blood meal. The next step is carried 
out by the Malpighian tubules (MTs), which are bathed directly by the hemolymph and are divided into two different segments (Figure 1). The distal (upper) segment, secretory part of the MTs, under the stimulus of insect diuretic hormones, rapidly transports the fluid from the hemolymph to the MTs lumen (Maddrell 1969, 1976). Besides the transported fluid being isosmotic, when compared to the hemolymph, it has much higher potassium content and lower sodium content. The proximal (lower) segment, reabsorptive part of MTs, modifies the tubular fluid by the transport of hyperosmotic $\mathrm{KCl}$ solution from MTs lumen to the hemolymph. This especial transport results in the elimination of a fluid considerably hyposmotic to hemolymph, with a similar potassium content (Maddrell 1964a, b).

The mechanism of MTs action is attractive from the physiological point of view for two main reasons. The first and more important one is that, during diuresis, these tubules can transport fluids at a very high rate. Secondly, earlier studies have shown that this diuresis is induced by a very potent insect diuretic hormone that causes a 1000-fold post-feeding increase in the rate of fluid transport by MTs (Maddrell 1964a, b, Maddrell et al. 1993). Rapid elimination of urine usually starts within 2-3 min after feeding and lasts for the next $3 \mathrm{~h}$, during which the insect may lose $40-50 \%$ of the mass of the ingested meal. After blood meal, the distention of the abdomen is sensed by stretch receptors in the abdominal cuticle, which trigger the release of diuretic hormones by a neuro-secretory system located in the Rhodnius prolixus mesothoracic ganglion and associated abdominal nerves (Maddrell et al. 1993, Orchard et al. 1989). It is also suggested by other authors that this fast fluid secretion is interrupted also by the influence of anti-diuretic insect hormones (Quinlan et al. 1997, O'Donnell and Quinlan 1998, Gäde 2004). At the present time only a few antidiuretic hormones are known. The antidiuretic hormones, in contrast with the diuretic hormones are those that decrease the loss of water in the insect from inhibition of the secretions of MTs and/or by reabsorption of ions and water in the hindgut (rectal sacs). Two antidiuretic polypeptides have been isolated from corpora cardica (CC) of the desert locust, Schistocerca gregaria (Gäde 2004): a) the neuroparsins, which act the level of the rectum (Girardie et al. 2001); and b) the ion- transport peptide (ITP), which stimulate ions and water reabsorption on the ileum (King et al. 1999).

As it was shown in the introduction, the insect Rhodnius prolixus has a very efficient organ of fluid secretion represented by very well adapted MTs. In this review we will discuss the hormonal regulation of fluid transport in the Rhodnius prolixus MTs and the transporters involved in this process.

\section{Malpighian TUbules}

The Malpighian tubules of insects consist of a long tubular structure formed of a single layer of epithelial cells and closed at on end. Generally, the tubules are free in the hemocoel, which opens into the alimentary canal at the junction of the midgut and hindgut. In Rhodnius prolixus MTs may be discharged directly into the rectum (Stobbart and Shaw 1964). The tubules vary from $2 \mathrm{~mm}$ to more than $100 \mathrm{~mm}$ in length and from 30 to $100 \mu \mathrm{m}$ in diameter. In some species, a marked morphological differentiation of the tubules may be evident. For example, the tubules of Rhodnius prolixus there is an evident transition between the distal and proximal portions characterized by a change in the striated border from the honeycomb to the brush-border type (Figure 1). Only the distal region is the site of urine secretion and hemolymph filtration. The proximal region is a reabsorptive site (Wigglesworth 1931).

The distal tubule mainly secretes ions $\left(\mathrm{Na}^{+}, \mathrm{K}^{+}\right.$, $\mathrm{Cl}^{-}$) and water, whereas the proximal tubule reabsorbs $\mathrm{K}^{+}$and $\mathrm{Cl}^{-}$but not water. The osmotic permeability of the proximal third of the proximal tubule is reduced, so water is not reabsorbed along $\mathrm{KCl}$. The combined actions of isosmotic fluid secretion by the distal MTs and $\mathrm{KCl}$ reabsorption by the proximal tubule preserve hemolymph osmolality and $\mathrm{K}^{+}$concentration after ingestion of a hyposmotic blood meal (O'Donnell et al. 1982, Haley and Donnell 1997).

\section{Transport in distal tubule}

The distal segment of MTs is responsible for the rapidly transport of isosmotic fluid from the hemolymph to the MTs lumen (Maddrell 1969, 1964b). There is agreement that, in distal Rhodnius prolixus MTs the primary active ion pump is an apical vacuolar-type $\mathrm{H}^{+}$-ATPase that transfers $\mathrm{H}^{+}$from cell to the lumen (Wieczorek et 


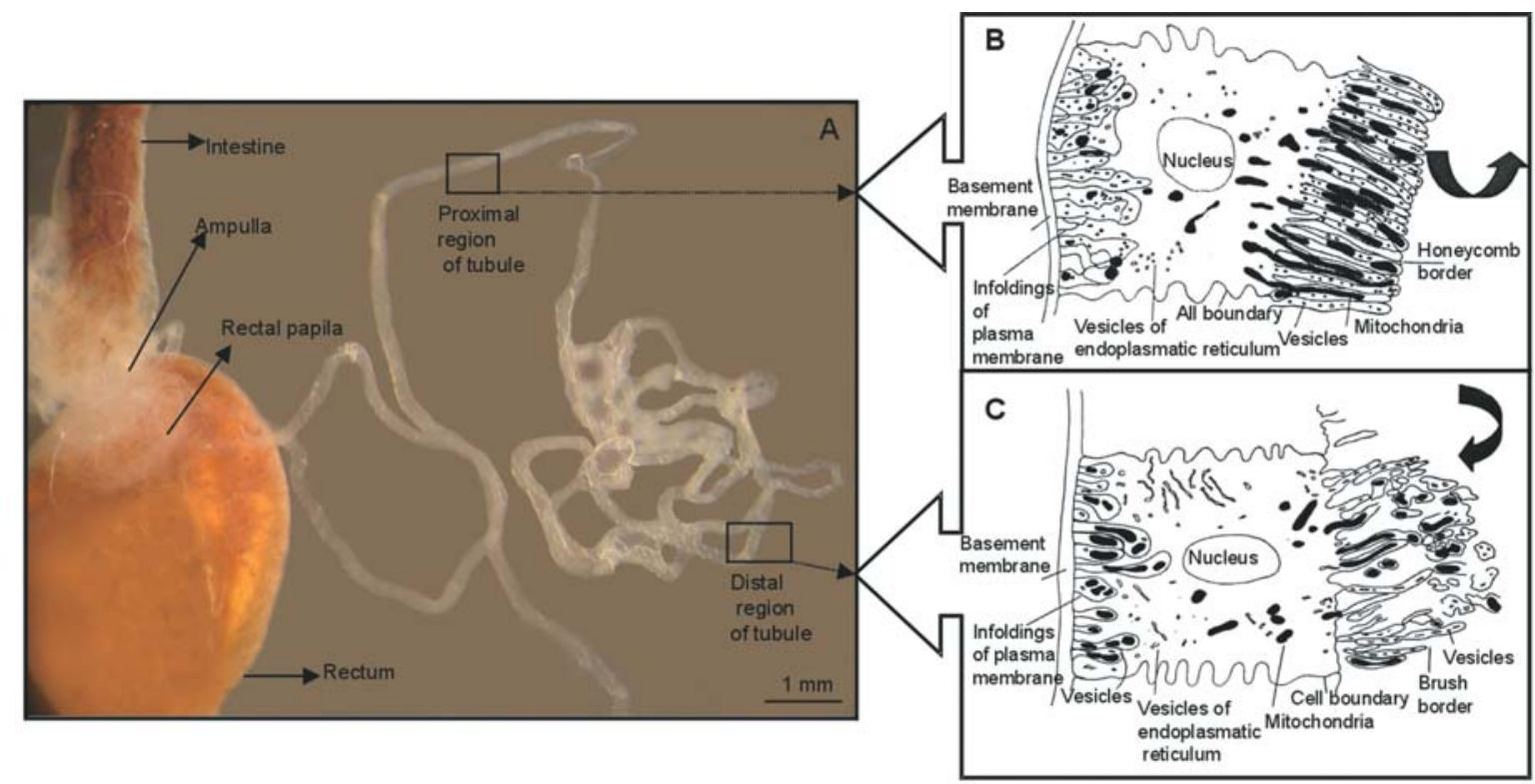

Fig. 1 - Excretory System of Rhodnius prolixus. A) Excretory system and the posterior part of the alimentary canal. In evidence, it is shown only one complete Malpighian tubule; B) Schematic diagrams of a cell from the distal region of a Malpighian tubule showing the regular cytoplasmic filaments of the honeycomb border; C) Schematic diagrams of a cell from the proximal region of a Malpighian tubule showing the irregular filaments of the brush border. Arrows indicate directional flux of secretion on Malpighian tubule (modified from Wigglesworth and Salpeter 1962).

al. 1989, Maddrell and O'Donnell 1992). This maintains a proton gradient across the apical membrane that drives movement of cations from cell to lumen via the apical proton exchangers $\mathrm{Na}^{+} / \mathrm{H}^{+}$and/or $\mathrm{K}^{+} / \mathrm{H}^{+}(\mathrm{Mc}-$ Elwain 1984, Ianowski and O'Donnell 2001). The $\mathrm{H}^{+}$ATPase also establishes a favorable electrical gradient for movement of $\mathrm{Cl}^{-}$from cell to lumen, and water movement is a consequence of active ion transport and this process is probably facilitated by water channels. Other transporters, whose role is not fully understood in MTs were described in apical membrane such as the $\mathrm{K}^{+}-\mathrm{Cl}^{-}$cotransporter, the urate-anion exchanger, several $\mathrm{K}^{+}$channels and different $\mathrm{Cl}^{-}$channels (Gutierrez et al. 2004). At the basolateral cell membrane the entry of ions into distal tubule involves a bumetanidesensitive $\mathrm{Na}^{+} / \mathrm{K}^{+} / 2 \mathrm{Cl}^{-}$cotransporter, ouabain-sensitive $\mathrm{Na}^{+} / \mathrm{K}^{+}$-ATPase and $\mathrm{Cl}^{-}-\mathrm{HCO}_{3}$ - exchanger (O'Donnell et al. 1982, Gutierrez et al. 2004).

\section{Transport in proximal tubule}

The proximal part of MTs modifies the fluid formed by distal tubule by the reabsorption of the hyperosmotic
KCl solution (Maddrell and Phillips 1975). The osmotic permeability of the proximal tubule is reduced, so water is not reabsorbed along with $\mathrm{KCl}$ (O'Donnell et al. 1982). The $\mathrm{K}^{+}$reabsorption by the proximal MTs involve an apical $\mathrm{H}^{+} / \mathrm{K}^{+}$-ATPase which exchanges luminal $\mathrm{K}^{+}$by cellular $\mathrm{H}^{+}$and it can be inhibited by omeprazole and $\mathrm{SCH} 28080$. The movement of $\mathrm{K}^{+}$from proximal tubule cell to hemolymph appears to involve the $\mathrm{Ba}^{+}$-sensitive $\mathrm{K}^{+}$channels (Haley and Donnell 1997). Reabsorption of $\mathrm{K}^{+}$is accompanied by equimolar reabsorption of $\mathrm{Cl}^{-}$. The effects of $\mathrm{Cl}^{-}$channel blockers suggest the presence of $\mathrm{Cl}^{-}$channels mediating movement of $\mathrm{Cl}^{-}$from cell to hemolymph. Movement of $\mathrm{Cl}^{-}$ from lumen to cell may involve $\mathrm{Cl}^{-} / \mathrm{HCO}_{3}$ - exchangers that are insensitive to SITS or DIDS (the stilbene derivates are known to affect both $\mathrm{Cl}^{-} / \mathrm{HCO}_{3}-$ exchange processes and channels $\mathrm{Cl}^{-}$, but are inhibited indirectly by acetazolamide (Boron 1983, Tilmann et al. 1991, Dijkstra et al. 1995). Importantly, exchange of $\mathrm{Cl}^{-}$ by $\mathrm{HCO}_{3}$ - prevents acidification of the lumen through operation of the $\mathrm{H}^{+} / \mathrm{K}^{+}$-ATPase. Part of the $\mathrm{H}^{+}$and $\mathrm{HCO}_{3}$ - ions present in the tubule lumen may combine to form $\mathrm{H}_{2} \mathrm{CO}_{3}$, a reaction that is catalyzed by carbonic 
anhydrase (CA), which dissociate in to $\mathrm{H}_{2} \mathrm{O}$ and $\mathrm{CO}_{2}$. The produced $\mathrm{CO}_{2}$ entry in the cell, re-combines with $\mathrm{H}_{2} \mathrm{O}$ producing $\mathrm{H}_{2} \mathrm{CO}_{3}$ (reaction that is also catalyzed by the $\mathrm{CA}$ ), which contributes to the driving force for $\mathrm{Cl}^{-}$entry in the cell via $\mathrm{Cl}^{-} / \mathrm{HCO}_{3-}$ exchanger (Haley and Donnell 1997).

\section{Regulation of Malpighian Tubules Transport}

The control of water balance and ionic transport is extremely important for the maintenance of insect homeostasis. A variety of factors have been identified which stimulate or inhibit basal secretion of ions and water transport in the MTs and contribute toward the high rate of transport observed after a Rhodnius prolixus meal (Gäde 2004, Spring 1990). Among several hormones and peptide we will discuss the most important, such as: A) Serotonin or 5-hydroxytryptamine (5-HT); B) The Corticotropin-Releasing Factor; C) Kinin); D) Cardioacceleratory Peptides (CAPs).

\section{Serotonin or 5-hydroxytryptamine (5-HT)}

Since nerves are not connected to MTs, the regulation of this epithelial transport is mediated via intrinsic mechanisms and via messengers that circulates in the hemolymph. After Rhodnius prolixus blood meal, distension of the abdomen is observed. The abdominal distention is sensed by stretch receptors in the abdominal cuticle, which trigger the release of serotonin and diuretic peptides from a variety of potential sources, including neurons located in the central nervous system, mesothoracic ganglia and the corpus cardiacum (Chiang and Davey 1988).

It was demonstrated before that serotonin, a well know neurohormone, is released into the hemolymph of a fed Rhodnius prolixus within one minute after feeding starts (Maddrell 1963, Lange et al. 1989). The serotonin is produced by, and released from a neurosecretory system located in the Rhodnius prolixus mesothoracic ganglion mass and associated abdominal nerves, and the serotonin content of secretory system is reduced during feeding (Orchard et al. 1989). The five serotonin-like immunoreactive dorsal unpaired median (DUM) neurons were found to represent a subpopulation in a group of ten DUM neurons located in the mesothoracic ganglionic mass and associated with the abdominal nerves.
Each abdominal nerve receive projections from two DUM neurons, only one of which was serotonin-like immunoreactive. The five DUM neurons in Rhodnius prolixus appear to represent a subpopulation of DUM neurons containing serotonin (Orchard et al. 1989).

During feeding in Rhodnius prolixus, serotonin concentration increases rapidly in the hemolymph from the low values found in the resting insect. It reaches a peak concentration of about $10^{-7} \mathrm{~mol} \times \mathrm{l}^{-1}$ after $5 \mathrm{~min}$ and then steadily declines to a proximal level by $1 \mathrm{~h}$ after start of feeding (Lange et al. 1989). The increased hemolymph serotonin concentration is correlated with an elevated rate of diuresis in Rhodnius prolixus (Maddrell 1991). Was found that Rhodnius prolixus MTs have receptors for serotonin that can be blocked by ketanserin and spiperone, known in vertebrate systems to be specific blockers for a particular subclass of serotonin receptors (Berridge 1972). The serotonin activates adenylate cyclase in cell membrane isolated from MTs of Rhodnius prolixus, increasing cyclic AMP second messenger. Isolated MTs can be stimulated to secrete at the maximal rate by addition of exogenous cAMP to the bath saline solution (Maddrell 1991). Montoreano et al. 1990 examined the fluid secreted by Rhodnius prolixus and detected that cAMP was released in the rectal ampulla, suggesting that it could be an important factor in the in vivo metacyclogenesis of Trypanosoma cruzi.

Stimulation of MTs with serotonin produces a characteristic triphasic change in transepithelial potential (TEP) (Ianowski and O'Donnell 2001). The TEP initial value is approximately $-25 \mathrm{mV}$, lumen negative in not stimulated tubules. Upon stimulation with serotonin the TEP shifts from $-33 \mathrm{mV}$ in phase 1 to $+30 \mathrm{mV}$ in phase 2 and $-32 \mathrm{mV}$ in phase 3 . Each of the three phases of the electrical signal is attributed to the activation of a particular ion transporter. There are only minor changes in basolateral membrane potential in response to serotonin, so the changes in transepithelial potential primarily reflect changes in apical membrane potential. Ion substitution and pharmacological experiments suggest that the three phases of the response of transepithelial potential to serotonin correspond to sequential activation of an apical chloride channel, an apical vacuolar type $\mathrm{H}^{+}$ATPase and a basolateral $\mathrm{Na}^{+}: \mathrm{K}^{+}: 2 \mathrm{Cl}^{-}$cotransporter (Ianowski and O’Donnell 2001). 
The $\mathrm{Na}^{+} / \mathrm{K}^{+}$-ATPase participates in transepithelial transport and cell volume regulation in MTs of Rhodnius prolixus (Caruso-Neves et al. 2001). Serotonin, the primary diuretic agent in Rhodnius prolixus released during meal, inhibits the $\mathrm{Na}^{+} / \mathrm{K}^{+}$pump, thereby bringing about the stimulation of transepithelial $\mathrm{Na}^{+}$secretion (Grieco and Lopes 1997). The inhibition is thought to increase intracellular $\mathrm{Na}^{+}$concentration, causing $\mathrm{Na}^{+}$ and water movement to the lumen of the tubule and thus increasing the rate of fluid secretion. This hypothesis is supported by observation that ouabain increases the fluid secretion in isolated and unstimulated MTs (Nicolson 1993).

That transepithelial secretion continues in the presence of ouabain confirms the central role of the $\mathrm{V}$ type $\mathrm{H}^{+}$-ATPase in powering transepithelial transport (Ianowski and O'Donnell 2001, Beyenbach et al. 2000).

\section{Serotonin and water transport}

Serotonin has also an important function in water transport in Rhodnius prolixus MTs. Cells membranes are exquisitely selective barriers that control the solute composition of enclosed compartments by regulating the entry of ions, solutes and water into cells. In general, osmotic forces drive water through the plasma membrane via selective channels called aquaporins (AQP) that are responsible for the rapid water fluxes through cell membranes (Agre et al. 1993, Borgnia et al. 1999).

Aquaporins are widely distributed in different species, and different homologues have been identified in several mammalian tissues (Borgnia et al. 1999). Paracellular and transcellular routes have been proposed to explain transepithelial water movement in MTs of insect Rhodnius prolixus (Whittembury et al. 1986, Hernandez et al. 2001). Studies have indicated that the osmotic water permeability, both basal and serotonin stimulated, of basolateral membrane of Rhodnius prolixus MTs can be inhibited partially with mercurial reagents, suggesting that AQPs may be implicated in water secretion in this epithelium (Whittembury et al. 1986, Echevarria et al. 2001). Using the Xenopus laevis oocytes expression system the same authors provide evidences that this transport is secondary to water permeability via aquaporins. The aquaporin related gene was cloned from Rhodnius prolixus MTs and called RP-MIP (Echevarria et al. 2001). Water secretion through MTs is essential for the transmission of the protozoa Tripanosoma cruzi, cause of Chagas disease. The Tripanosoma cruzi is transmitted by Rhodnius prolixus (Dias et al. 1997) and it is found in the intestinal tract. The protozoan transmission to mammalian host occurs after blood sucking leading to stimulation of MTs secretion and increases the volume of feces in the rectum stimulating defecation, which excrete the parasites (Fistein and Chowdhury 1969, Kollien and Schaub 1998).

It is generally accepted that water movement is secondary to ion transport in MTs. The ion movement creates the osmotic force necessary to water transport. The pathway of water movement has been investigated experimentally in the distal tubule of Rhodnius proli$x u s$, in which stimulation of fluid secretion by serotonin did not increase the already high osmotic permeability. Fluid secretion rates in the distal MTs appear to be regulated by changes in solute transporters (O'Donnell et al. 1982). In addition, our group recently demonstrated in Rhodnius prolixus MTs that water transporter can also be regulated by insect involved diuretic. We showed that after 6 hours of MTs incubation with serotonin or cAMP, time enough to see the increase of messenger RNA after stimulation with hormones for many genes (Hasler et al. 2003) an increase of approximately 2 folds in the expression of Rp-MIP mRNA is observed (Martini et al. 2004). But stimulation with both cAMP and serotonin was not able to additionally increase the levels of mRNA message (Martini et al. 2004). These results are in agreement with other authors that demonstrated the raise of serotonin concentration by about three times within the hemolymph just after 5 minutes of Rhodnius prolixus blood feeding. This changes lead to an augmented hemolymph cyclic AMP leading to an increased diuresis (Lange et al. 1989, Maddrell et al. 1991).

\section{THE CORTICOTROPIN-RELEASING FACTOR}

The corticotropin-releasing factor related diuretic hormone family (CFR-related DH) is also able to increase cyclic AMP content, transepithelial potential and rate of secretion in insect MTs (O'Donnell et al. 1996, Coast et al. 2002). These peptides have some structural resemblance to the vertebrate CRFs, which include urotensin, urocortin, and sauvagine. CFR-related DHs have been 
isolated from locusts, crickets, cockroaches, termites, beetles, mosquitoes, fly and sphingid moths (Coast et al. 2002).

Using fluorescence immunohistochemistry and immunogold labeling with antibodies to the Locusta CRF like diuretic hormone (Locusta-DH), Te Brugge et al. 1999 have mapped the distribution of neurones displaying this phenotype in Rhodnius prolixus. Strong LocustaDH-like immunoreactivity was found in numerous neurons of the central nervous system (CNS) and, in medial neurosecretory cells of the brain and in posterior lateral neurosecretory cells of the mesothoracic ganglionic mass (MTGM). Positively stained neurohemal areas were found associated with the corpus cardiacum (CC) and on abdominal nerves.

Extracts of the $\mathrm{CC}$ and abdominal nerves caused an increase in the rate of secretion and an increase in the level of cyclic AMP in the MTs of fifth-instar (the last larval stage) Rhodnius prolixus. The presence of the peptide in neurohemal terminals of the $\mathrm{CC}$ and abdominal nerves that are distinct from serotonin-containing terminals indicates that the peptide is capable of being released into the hemolymph and that this release can be independent of the release of serotonin (Te Brugge et al. 1999). CRFlike peptides have been demonstrated to increase the rate of cAMP contend and also Rhodnius prolixus MTs fluid secretion. In this context it was suggested that serotonin and CRF-like peptide act synergistically to accelerating fluid secretion by the MTs and stimulating adenylate cyclase from the tubules (Maddrell et al. 1993, Te Brugge et al. 1999).

\section{KININ}

Kinin peptides were originally isolated from the cockroach, having activity on hindgut. These peptides have been shown to increase the rate of secretion of isolated MTs of several species of insects. Kinin-like peptides are co-localized with CRF-like peptides in neurohemal sites on the abdominal nerve. The kinin-like peptide is released in the hemolymph after blood meal, but this peptide do not stimulated secretion from isolated MTs in Rhodnius prolixus (Te Brugge et al. 2002).

\section{CARdioAcCeleratory PePtides (CAPs)}

Cardioacceleratory Peptides (CAPs) are neuropeptides originally isolated from CNS of tobacco hawk moth
Manduca sexta. The CAPs act as cardiostimulatory neurohormones and influence various stage-patterns of behavior in Manduca (Tublitz et al. 1991, Te Brugge et al. 2002). The CAPs have also been implicated in the control of fluid secretion by the Malpighian tubules of Drosophila melanogaster, in the control of heart and gut activity in Locusta migratoria, and in the regulation of cardiac activity in crustaceans (Davies et al. 1995, Stangier et al. 1988).

Early biochemical studies using low-pressure column chromatography fractionated the CAPs into two distinct groups, $\mathrm{CAP}_{1}$ and $\mathrm{CAP}_{2}$ which are subdivided into at least two $\mathrm{CAP}_{1} \mathrm{~s}$ (1a and $1 \mathrm{~b}$ ) and three $\mathrm{CAP}_{2} \mathrm{~s}$ (2a, 2b and 2c) (Tublitz and Truman 1985a, b, c, Cheung et al. 1992).

The peptide CAP2b stimulates tubule fluid secretion via the cGMP second messenger system in Drosophila (Davies et al. 1995). It has been suggested that modulate a vacuolar-type $\mathrm{H}^{+}$-ATPase (O'Donnell et al. 1996). Exogenous cGMP is effective at doses as low as $3.5 \mu \mathrm{molxl}^{-1}$ in Drosophila melanogaster, and tubule levels of this nucleotide are elevated by both nitric oxide and cardioactive peptide $\left(\mathrm{CAP}_{2 b}\right)$ isolated originally from the hawkmoth Manduca sexta (Davies et al. 1995).

Opposed to these findings, Quinlan et al. 1997 showed that cardioacceleratory peptide $2 \mathrm{~b}\left(\mathrm{CAP}_{2 \mathrm{~b}}\right)$ or cGMP are powerful inhibitors of fluid secretion from MTs. They suggest that $\mathrm{CAP}_{2 b}$ act as an antidiuretic hormone in Rhodnius prolixus and that effects are mediated by cGMP. This inhibition can be reversed by application of high concentration of cAMP. Secretion rates of serotonin stimulated MTs are suppressed by low doses of $\mathrm{CAP}_{2 b}$ or cGMP. The intracellular levels of cGMP in isolated MTs increased in response to $\mathrm{CAP}_{2}$, suggested that cGMP may act as an intracellular second messenger for $\mathrm{CAP}_{2 \mathrm{~b}}$ in Rhodnius prolixus. In addition, tubule cGMP level increase as urine output from fed Rhodnius prolixus declines, consistent with a physiological role for cGMP in termination of diuresis.

O'Donnell and Quinlan 1998 have demonstrated that cGMP has effects antagonistic to those of cAMP in Rhodnius prolixus tubules and have further characterized the effects of cGMP on tubular secretion. The antagonism may possibly occur because a cAMP phosphodiesterase is activated by cGMP, leading to the rapid dis- 
appearance of second messenger that mediates diuretic hormone activity (Gäde 2004).

\section{CONCLUSION}

In this review we discussed the importance of Rhodnius prolixus MTs as a very interesting model of study of ion and water transport regulated by hormones and different peptides. Between meals Rhodnius prolixus MTs cells are in the quiet period (between meals) were the fluid transport is a thousand times more slowly than during the action of diuretic peptides (after meal). Those peptides are able to increase Rhodnius prolixus MTs fluids transport at rates several times higher than any epithelial cells of their host. The transport regulation of MTs is certainly one of the key points for insect homeostasis and, certainly, it is also important for Trypanosoma cruzi transmission.

\section{RESUMO}

Os túbulos de Malpighi (TMs) de Rhodnius prolixus são reconhecidos por serem excelentes modelos para o estudo da secreção de fluidos e íons devido a grande diurese que ocorre quando esses animais se alimentam de sangue. O inseto, após alimentação, pode aumentar seu peso corporal inicial em até 10-12 vezes, o que leva a rápida ativação do sistema excretor, que elimina $40-50 \%$ do fluido corporal. A secreção de íons e água é estimulada 1000 vezes pela serotonina e pelos hormônios diuréticos. Esses hormônios agem sinergicamente ativando a adenil ciclase das células dos TMs, aumentando os níveis intracelulares de AMPc. Os hormônios anti-diuréticos também têm um importante papel na manutenção dos fluídos corporais do Rhodnius prolixus. Várias horas após a alimentação do inseto ocorre uma redução do fluxo urinário, o que foi sugerido ser decorrente da diminuição da liberação dos hormônios diuréticos ou da anti-diurese envolvendo o peptídeo cardioaceleratório 2b (CAP2b) e o GMPc. Neste artigo é discutida a regulação hormonal do transporte de fluido nos MTs de Rhodnius prolixus.

Palavras-chave: túbulos de Malpighi, Rhodnius prolixus, hormônios, secreção de fluido.

\section{REFERENCES}

Agree P, Preston GM, Smith BL, Jung JS, Raina S, Moon C, Guggino WB and Nielsen S. 1993.
Aquaporin CHIP: the archetypal molecular water channel. Am J Physiol 265: F463-476.

BERRIDGE MJ. 1972. The mode of action of 5-hydroxytrytamine. J Exp Biol 56: 311-321.

Beyenbach KW, Pannabecker TL and Nagel W. 2000. Central role of the apical membrane $\mathrm{H}^{+}$-ATPase in electrogenesis and epithelial transport in Malpighian tubules. J Exp Biol 203: 1459-1468.

Borgnia M, Nielsen S, Engel A And Age P. 1999. Cellular and molecular biology of the aquaporin water channels. Annu Rev Biochem 68: 425-458.

BORON WF. 1983. Transport of $\mathrm{H}^{+}$and of ionic weak acids and bases. J Memb Biol 72(1-2): 1-16.

Caruso-Neves C, Silva IV, Morales MM and Lopes AG. 2001. Cytoskeleton elements mediate the inhibition of the $\mathrm{Na}^{+} / \mathrm{K}^{+}$ATPase activity by PKC in Rhodnius prolixus Malpighian tubules during hyperosmotic shock. Arch Insect Biochem Physiol 48: 81-88.

Cheung CC, Loi PK, Sylwester AW, Lee TD And TUbLitZ NJ. 1992. Primary structure of a cardioactive neuropeptide from the tobacco hawkmoth, Manduca sexta. FEBS Lett 313: 165-168.

ChIANG RG AND DAVEY KG. 1988. A novel receptor capable of monitoring applied pressure in the abdomen of an insect. Science 241: 1665-1667.

Coast GM, Orchard I, Phillips JE And Schooley DA. 2002. Insect diuretic and antidiuretic hormones. Adv Insect Physiol 29: 279-409.

Davies SA, Huesmann GR, Maddrell SH, O'DonNEL MJ, SKAER NJ, Dow JA AND tublitZ NJ. 1995. CAP2b, a cardioacceleratory peptide, is present in Drosophila and stimulates tubule fluid secretion via cGMP. Am J Physiol 269 (6 Pt 2): R1321-1326.

Dias JC, Silveira AC AND SchofIEld CJ. 1997. The impact of Chagas disease control in Latin America: a review. Mem Inst Oswaldo Cruz 97: 603-612.

Dijkstra S, Leyssens A, Van Kerkhove E, Zeiske W AND STEELS P. 1995. A cellular pathaway for $\mathrm{Cl}^{-}$ during fluid secretion in ant Malpighian tubules: Evidence from ion-sensitive microelectrode studies? J Insect Physiol 41: 695-703.

ECheVARria M, Ramirez-Lorca R, Hernandez CS, Gutierrez A, Mendez-Ferrer S, Gonzalez E, Toledo-Aral JJ, ILUNDAIN AA AND WhitTEMBURY G. 2001. Identification of a new water channel (Rp-MIP) in the Malpighian tubules of the insect Rhodnius prolixus. Pflügers Archiv Euro J Physiol 442(1): 27-34. 
FisTEIN B AND CHOWDHURY MN. 1969. The uptake of Trypanosoma cruzi by $R$. prolixus and its later excretion. Trans R Soc Trop Med 63: 883-884.

GÄDE G. 2004. Regulation of intermediary metabolism and water balance of insects by neuropeptides. Annu Rev Entomol 49: 93-113.

Girardie J, ChaAbihi H, Fournier B, Lagueux M AND GIRARDIE A. 2001. Expression of neuroparsin cDNA in insect cells using baculovirus vectors. Arch Insect Biochem Physiol 46: 26-35.

GRIECO MAB AND LOPES AG. 1997. 5-hydroxytryptamine regulates the $\left(\mathrm{Na}^{+}+\mathrm{K}^{+}\right)$ATPase activity in Malpighian tubules of Rhodnius prolixus: evidence for involvement of G-protein and cAMP-dependent protein kinase. Arch Biochem Biophys 36: 203-214.

Gutierrez AM, Hernandez CS ANDD WhitTembury G. 2004. A model for fluid secretion in Rhodnius upper Malpighian tubules (UMT). J Memb Biol 202: 105-114.

HaLEY C AND DonNell M. 1997. K+ reabsorption by the lower Malpighian tubule of Rhodnius prolixus: inhibition by $\mathrm{Ba}^{2+}$ and blockers of $\mathrm{H}^{+} / \mathrm{K}^{+}$-ATPases. J Exp Biol 200(Pt 1): 139-147.

Hasler U, Mordasini D, Bianchi M, Vandewalle A, FERAILle E AND MARTIN PY. 2003. Dual influence of aldosterone on AQP2 expression in cultured renal collecting duct principal cells. J Biol Chem 278: 21639-21648.

Hernandez CS, Gutierez AM, Vargas-Janzen A, Noria F, Gonzalez E, RuIZ V AND WhitTembury G. 2001. Fluid secretion in Rhodnius upper Malpighian tubules (UMT): water osmotic permeabilities and morphometric studies. J Memb Biol 184: 283-290.

IANOWSKI JP AND O'DonNELl MJ. 2001. Transepithelial potential in Malpighian tubules of Rhodnius prolixus: lumen-negative voltages and the triphasic response to serotonin. J Insect Physiol 46: 107-117.

King DS, Meredith J, WANG YJ AND Phillips JE. 1999. Biological actions of synthetic locust ion transport peptide (ITP). Insect Biochem Mol Biol 30: 489-498.

Kollien AH And Schaub GA. 1998. Development of Trypanosoma cruzi after starvation and feeding of the vector - a review. Tokai J Exp Clin Med 23: 335-340.

LANGE AB, ORCHARD I AND BARRETT FM. 1989. Changes in hemolymph serotonin levels associated with feeding in the blood-sucking bug, Rhodnius prolixus. J Insect Physiol 35: 393-399.

LENT H AND WygODZINSKY P. 1979. Revision of the Triatominae (Reduviidae, Hem.) and their significance as vector of Chagas' disease. Bull Am Museum Nat Hist 163: $127-520$.

MADDRELL SH. 1964a. Excretion in the blood-sucking bug, Rhodnius prolixus Stal. 3. The control of the release of the diuretic hormone. J Exp Biol 41: 459-472.

MADDRELL SH. 1964b. Excretion in the blood-sucking bug, Rhodnius prolixus Stal. II. The normal course of diuresis and the effect of temperature. J Exp Biol 41: 163-176.

MAdDRell SH AND O'DonNell MJ. 1992. Insect Malpighian tubules: V-ATPase action in ion and fluid transport. J Exp Biol 172: 417-429.

Maddrell SH, Herman WS, Mooney RL and OVerTON JA. 1991. 5-Hydroxytryptamine: a second diuretic hormone in Rhodnius prolixus. J Exp Biol 156: 557-566.

MADDRELl SHP. 1963. Excretion in the blood-sucking bug, Rhodnius prolixus Salt.I. The control of diuresis. J Exp Biol 40: 247-256.

MADDRELL SHP. 1969. Secretion by Malpighian tubules of Rhodnius. The movements of ions and water. J Exp Biol 51: 71-97.

MADDRELL SHP. 1976. Functional design of the neurosecretory system controlling diuresis in Rhodnius prolixus. Am Zool 16: 131-139.

MADDRELL SHP. 1991. The fastest fluid-secreting cell known: the upper Malpighian tubule cell of Rhodnius. BioEssays 13: 357-362.

MADDRELl SHP AND PHILliPS JE. 1975. Secretion of hypo-osmotic fluid by the lower Malpighian tubules of Rhodnius prolixus. J Exp Biol 62: 671-683.

Maddrell SHP, Herman WS, FARndale RW AND RIEGEL JA. 1993. Synergism of hormones controlling epithelial fluid transport in an insect. J Exp Biol 174: 65-80.

Martini SV, Goldenberg RC, Fortes FS, Camposde-Carvalho AC, Falkenstein D and Morales MM. 2004. Rhodnius prolixus Malpighian tubules aquaporin expression is modulated by 5-hydroxytryptamine. Arch Insect Biochem Physiol 57: 133-141.

MCELWAIN DLS. 1984. A theoretical investigation of fluid transport in the Malpighian tubules of an insect, Rhodnius prolixus Salt. Proc R Soc Lond B Biol Sci 222: 363-372.

Montoreano R, Triana F, Abate T and RangelAldo R. 1990. Cyclic AMP in the Malpighian tubule fluid and in the urine of Rhodnius prolixus. Gen Comp Endocrinol 77: 136-142.

NICOLSON SW. 1993. The ionic basis of fluid secretion in insect Malpighian tubules: advances in the last ten years. J Insect Physiol 39: 451-453. 
O’Donnell MJ AND Quinlan MC. 1998. Anti-diuresis in the blood-feeding insect Rhodnius prolixus Stal: antagonistic actions of cAMP and cGMP and the role of organic acid transport. J Insect Physiol 44: 561-568.

O’Donnell MJ, Aldis GK ANd Maddrell SH. 1982. Mensuraments of osmotic permeability in the Malpighian tubules of an insect, Rhodnius prolixus Stal. Proc R Soc Lond B Biol Sci Lon 216: 267-277.

O’Donnell MJ, Dow JA, Huesmann GR, Tublitz NJ AND MAdDRELL SH. 1996. Separate control of anion and cation transport in Malpighian tubules of Drosophila melanogaster. J Exp Biol 199 (Pt 5): 1163-1175.

OrchaRd I, LANGE AB, COOK H AND RAMIREZ JM. 1989. A subpopulation of dorsal unpaired median neurons in the blood-feeding insect Rhodnius prolixus displays serotonin-like immunoreactivity. J Comp Neurol 289: 118-28.

Quinlan MC, Tublitz NJ AND O’DonNell MJ. 1997. Anti-diuresis in the blood-feeding insect Rhodnius prolixus Stal: the peptide CAP2b and cyclic GMP inhibit Malpighian tubule fluid secretion. J Exp Biol 200 (Pt 17): 2363-2367.

SPRING JH. 1990. Endocrine regulation of diuresis in insects. J Insect Physiol 36(1): 13-22.

Stangier J, Hilbich C, Dircksen H And Keller R. 1988. Distribution of a novel cardioactive neuropeptide (CCAP) in the nervous system of the shore crab Carcinus maenas. Peptides 9: 795-800.

StobBart RH AND SHAw J. 1964. Salt and water balance: excretion. In: The Physiology of InSECTA. RockSTEIN M (Ed), New York: Academic Press 3: 100-258.

Te Brugge VA, Mirksys SM, CoAst GM, Schooley DA AND ORCHARD I. 1999. The distribution of a CRFlike diuretic peptide in the blood-feeding bug Rhodnius prolixus. J Exp Biol 202 (Pt 15): 2017-2027.

Te Brugge VA, Schooley DA AND Orchard I. 2002. The biological activity of diuretic factors in Rhodnius prolixus. Peptides 23: 671-681.
Tilmann M, Kunzelmann K, Frobe U, Cabantchik I, LANG HJ, ENGLERT HC AND GREger R. 1991. Different types of blockers of the intermediate-conductance outwardly rectifying chloride channel in epithelia. Pflügers Archiv Euro Physiol 418: 556-563.

Tublitz N, BRINK DL, BROADIE KS, LOI PK AND SYLWESTER AW. 1991. From behavior to molecules: an integrated approach to the study of neuropeptides. Trends Neurosci 14: 254-259.

TUblitz NJ AND TRUMAN JW. 1985a. Intracellular stimulation of an identified neuron evokes cardioacceleratory peptide release. Science 228(4702): 1013-1015.

TUblitz NJ AND TRUMAN JW. 1985b. Insect cardioactive peptides. I. Distribution and molecular characteristics of two cardioacceleratory peptides in the tobacco hawk moth, Manduca sexta. J Exp Biol 114: 365-379.

TUBLITZ NJ AND TRUMAN JW. 1985c. Insect cardioactive peptides. II. Neurohormonal control of heart activity by two cardioacceleratory peptides in the tobacco hawk moth, Manduca sexta. J Exp Biol 114: 381-395.

WhitTembury G, Biondi AC, PAZ-Aliaga A, LinhaRES H, PARTHE V AND Linhares N. 1986. Transcellular and paracellular flow of water during secretion in upper segment of Malpighian tubule of Rhodnius prolixus: solvent drag of molecules of graded size. J Exp Biol 123: 71-92.

Wieczorek H, WeEdTh S, SChindlbeck M AND KLEIN U. 1989. A vacuolar-type proton pump in a vesicle fraction enriched with potassium transporting plasma membranes from tobacco hornworm midgut. J Biol Chem 264: 11143-11148.

WiggLesworth VB. 1931. The physiology of excretion in blood-sucking insect, Rhodnius prolixus (Hemiptera, Reduviidae) II.Anatomy and histology of excretory system. J Exp Biol 8: 428-442.

Wigglesworth VB AND SALPETER MM. 1962. Histology of the Malpighian tubules in Rhodnius prolixus Stahl (Hemiptera). J Insect Physiol 8: 299-307. 